\title{
Effect of Nitrobien Biofertilizer on Cytogenetic and Growth Parameters Alterations in Vicia faba
}

\author{
Nahla Osman Mohamed Ehsan \\ Botany Department, Faculty of Women For Arts, Science and Education \\ Ain Shams University, Cairo, Egypt
}

\begin{abstract}
The study objective evaluate the effect of Nitrobein biofertilizer on plant growth parameters and cytogenetic alterations through the mitotic and meiotic divisions of Vicia faba after treated with different doses (D, 2Dand 4D) compared with control. The variation in the content of the genetic material through G1, S, G2 at cell cycle had a proportion of cells entering the cell cycle at interphase as an indicator for cell proliferation and percentage of mitotic index by using cellular image analysis based on the relationship between DNA as Eeuchromatin and Heterochromatin and the Feulgen stain intensity, added to followed the chromosome behavior through $\mathrm{M}$ phases from cell cycle at mitotic and meiotic divisions, where the recorded results had a proportional relationship with biofertilizer doses (D,2Dand 4D) compared with control accompanied with the mutagenic effects as a results of chromosome aberration at metaphase stage represented by bridges, fragment and nondisjunction chromosome at anaphase based on the end-to-end fusions between sister chromosomes or sister chromatids end joining as a result telomere dysfunction and anomalies chromosomal types was permanent where its continued from somatic cells to gametic cells in meiotic division. On the other hand, there is a significant increase in growth parameters after treated with biofertilizer doses
\end{abstract}

Key word: Cytogenetic, Nitrobien biofertilizer, Telomere, Cell cycle, Eeuchromatin

\section{Introduction:}

Biofertilizer or "microbial inoculants" was considered the ecosystem friendly for high yielding cultivars, by the nutrients through the natural processes of nitrogen fixation which can be used with crops as a nitrogen fixing fertilizer, Gupta and Pandher (1996).

Nitrobien was one from different types of biofertilizer consists of nitrogen fixing bacteria (Azotobacter sp. and Azospirillum sp.), it is non Symbiotic for adequate supply of nitrogen is essential for plant nutrient and necessary to achieve high yield potential in crop also benefit for all field crops, vegetables and fruits, also suitable for all soil and sandy lands, as noted from Biofertilizer unit Ministry of Agriculture.

Jnawali, et al (2015) recorded that crop growth and yield increase after treated seed inoculation with Azotobacter sp. a free-living $\mathrm{N}_{2}$ - fixer, where increased plant length, dry weight, and nitrogen content added to increase in soil nitrogen and promoting effect on growth parameters on bamboo and maize and rice plant .

Corresponding Auther: dr.nahla.osman@gmail.com 
Kyi. et al ( 2019) study the effects of Biofertilizer on mung bean, cowpea, and soybean plant growth, nodulation, nitrogen fixation, nutrient uptake, and seed yield, Where they found the nitrogen is the component of amino acids \& protein and nucleic acids, stimulating plant growth through the synthesis of growth-promoting substances.Yaso, et al (2007) tested the effects of a biofertilizer Bradyrhizobium strains and Streptomyces griseoflavus on leguminous, cereal, and vegetable crops, they found that Bradyrhizobium japonicum SAY3-7 plus Bradyrhizobium alkane BLY3-8 and Streptomyces griseoflavus can be used together as biofertilizers on soybean and mung bean.

Some studies discussed the effect of biofertilizer on plant morphological and cytological views. Thoria et al (2003) studied the effect of two biofertilizers rhizobacterien and phosphoren on in Vicia faba, where they found a positively relationship between increase in biofertilizers doses and percentage of abnormal PMCs in Vicia faba. Abdel-Hamid (2007), studied the mutagenic potentiality of crop finisher fertilizer and cerealin biofertilizer on mitosis and meiosis yield production, she found a significant increase in mitotic activity of Vicia faba plant with different types of chromosome aberrations in mitotic and meiotic divisions

Measure of the nuclear DNA amount in nuclei studied by using image cytometry as more rapid accurate efficient method where there were some researchers followed the cell cycle and chromosome behavior by different procedures. Hammat et al (1991) and Glab et al (1994) said that it is possible with image cytometry determine the cell cycle analysis and study the plant cell culture regulation. On the other hand, the cytological techniques using to determine the quantifying chromosomal aberrations depended on aceto-carmine, aceto-orcein and feulgen stains to study the chromosomes behavior, number and sized from the plant meristematic tissues, such as root meristems (e.g., Vicia faba), pollen mother cells and pollen grains Natarajan (2005). Also, Jean Dufer, et al (1995) studied 2 types of nuclear textural phenotype analysis on G0/G1selected cell nuclei revealed, and they found that multidrug resistance could be associated with specific nuclear morphological changes which appeared to be a consequence of alterations occurring during selection by cytotoxic drugs .El-Shazly, and El-Sheik (2000) studded the effect of pesticides on the component of Allium cepa mitotic cycle by using image cytometric, where they found increase in cells in G0/G1 concomitant S, G2 and M phase. The mutational and cytogenetic effects of microbien, rhizobacterien and phosphoren on Vicia faba were studied Ehsan (2000) and she found that biofertilizers have a mitotic activity with increase in percent of mitotic index through the microscopic and image cytometric investigation. Garbay et al (1981) described the nuclear chromatin Image process to translate the relation between the amount of DNA and its Feulgen stain intensity.

Laura et al (2018) found that, a large number of satellite repeats recorded with $V$. faba where the Satellite repetitive sequences of Vicia faba DNA was considered a long arrays of tandem repeated units of genome model for cytogenetic studies in plants, and its contains a diverse set of satellite repeat. Also, for ensure chromosomal stability the there was a very important region in the end of the chromosomes called nucleo-protein complexes "capping" (Telomere) Lucie and Jiri (2012), where plant telomeres consist of about seven-base repeat TTTAGGG Jonathan $\boldsymbol{e t}$ al ( 2011) 
The aim of this study followed the positive or/and negative direction which may occur for the Vicia faba plant after treated with different doses of nitrobein biofertilizer through the growth parameters and cytogenetic alteration To determine from seedling to the plant maturity, by using a microscopic and Image analysis study for root merestematic cells to study cell cycle phases characteristics, the chromatin density and activity, and specially chromosomal structural aberrations and vitality at telomere region in mitotic division, added to predict the future of the first generation by studying the meiotic division chromosome in PMCs especially after treated with highest doses, where the recommended dose can be repeated several times during plant life until maturity

\section{Materials and Methods:}

Homogenous healthy seeds of Vicia faba L. (C.V. Giza 3) obtained from the Crop Research Institute, Agricultural Research Center (ARC), Giza, Egypt, and nitrobein biofertilizer obtained Ministry of Agriculture (Biofertilizer unit) with Instruction before planting mix the fertilized contents directly with the seeds, then plant them immediately with any type of soil and repeat the mixture before each irrigation around the plant several times.

Two types of experiments were carried out to study the effect of Nitrobien on plant growth parameters and cytogenetic alteration through the mitotic and meiotic divisions compared with control.

1- First experiment for cytogenetic study to analyses the nuclear image and determine cell cycle characteristic, at least five roots for each dose will be used after mix the seeds with different doses of Nitrobien as recommendation. The recommended dose was $200 \mathrm{~g}$ per fadan and the dosage used were $(\mathrm{D}, 2 \mathrm{D}, \& 4 \mathrm{D}$ ) where ( $\mathrm{D}$ : is a recommended dose $1.6 \mathrm{~g} / 100$ seeds, 2D and 4D: were $3.2 \mathrm{~g} / 100$ seeds , $4.8 \mathrm{~g} / 100$ respectively) compared with control . Incubated seeds were covered with swollen cotton in petry dishes until the root length reached to $2-3 \mathrm{~cm}$, then cut the root tips and fix it in Carnoy 's solution with Feulgen squash technique according to . Darlington and Lacour (1976).

At least 100 nuclei from each permanent slide with Feulgen stain root cells meristem was used for cytometric image analysis, each slide distribution according to DNA content by selected randomly from the middle part of the slide in the same conditions for the calibration of the Haploid, Diploid and Tetraploid value to measure the Integrated optical density (IOD) according to Dean (1980). Image analysis system was performed on (Leica quatiment 520 cell Image apparatus) this microphotometric scanning analysis system is composed of microcomputer and transmation microscope coupled to an electro-0ptical system, these assay were performed in Genetics Department of Faculty of Agriculture, Alexandria University according to Brugal (1984) and Moustafa et al (1988).

Five classes densitometry features include Integrated Optical Densities (IOD) will be distributed in haploid 1c DNA with DNA content 12.15 Pico gram and diploid 2c DNA was 24.3 Pico gram (pg.) Vant Hof (1974), nuclei 3c and 4c DNA content, where the (IOD) and nuclear area parameters two types of analysis were used to differentiate between $2 \mathrm{c}$ - DNA content nuclei $3 \mathrm{c}$ and $4 \mathrm{c}$ DNA content, added to the cell cycle phases classification which determined as percentages of cells interred to the were calculated. 
The Cell cycle phases evaluated by isolation the results of the G0/G1 ,S phase and , G2, G2/M cells according to the nuclear shape and size added to chromatin texture estimated, where DNA content was doubles with nuclear size increases during the cell cycle Mitchison (1971). The chromatin condensation in the nucleus computed as a various color degree (red and yellow) to indicate the chromatin activity (Euchromatin - Heterochromatin) as a response of Fulgen reaction Garbay et al (1981).

2- Second experiment for morphological and meiotic division cultivate the treated seeds with different doses (D, 2D, 4D) compared with control in pots filled with equal amount soil for study the effect of biofertilizer on growth parameters as the (root length for 12 days, and shoot length through 4 weeks, then 70 days from germination, added to the fresh and dry weight after 70 days as a biomass reproductively was determine, also the number of pods/plant and number of seeds/pant. On the other hand, at least 5 flower buds for each treated plants used to studied the pollen mother cells first and second meiotic division, where examine and prepare the slides by using aceto-carmine smear technique as Belling (1926), and Sharma and Sharma (1980)

Photo micrographs of the induced abnormalities were taken using (Carl Zeiss photo microscope III) with objective 40×, interference filter $560 \mathrm{~nm}$ and black and white TV camera with a pixel resolution $512 \times 512$, also, for nuclear image analysis a sensor video camera data analysis processor were visualized on TV monitor then scan it . Statistical analysis of data was conducted using t-test. The values of analyzes criteria were recorded as mean \pm standard error (S.E) the level of significance was to be highly significant $(\mathrm{P}<0.01)$, significant $(\mathrm{P}<0.05)$, or non significant $(\mathrm{P}>0.05)$.

\section{$\underline{\text { Results and Discussion : }}$}

Effect of nitrobien biofertilizer on cytogenetic and growth parameters alterations in Vicia faba were recorded in tables $(1,2,5,6)$ for the mitotic and meiotic divisions and tables $(3,4)$ respectively.

In eukaryote the cell cycle pass through cell growth, DNA replication, chromosomes distribution as a nucleic division, then the cell division leads to daughter cells or gametes Interphase is the time of cell growth and DNA duplication so the cells at cycle (G1, S, G2 ) can be distinguish by DNA content. Cytometric Image apparatus contributed to the study of cell cycle phases using feulgen stained nuclei, where in G1 DNA content is (2n) diploid, the DNA content increase from $2 n$ to $4 n$ tetraploid by the duplication through S-phase, then the cycle continue to G2 and M phase with 4n DNA content finally the DNA content return to $2 \mathrm{n}$ after cytokinesis, Cooper (2000). This is in a agreement with the results in Table (1), where the cell cycle analysis estimated by measurement Integrated optical density (I.O.D) of DNA content in Arbitrary Unit (A.U.) as an amount of DNA / pico gram, accompanied with DNA classes modal value as expressed in $\mathbf{C}$ on Feulgen-stained nuclei after treated with different doses of nitrobein biofertilizer on Vicia faba compared with control. There was a negatively proportion between the percentage of cells which have 2c nuclear diploid DNA content (included G1-postmitotic, G0 /G1 premitotic, telophase, anaphase-2c) with doses increase, where the percentage of treated cells with $\mathrm{D}$ and 2D recorded 70.27 and 70.03 respectively compared with control. G1 is known 
as the growth phase because sometimes a cell does not go immediately into the next phase and goes into a resign period G0 which can be a temporary state, or a permanent one i-e G1 a general decision for cell proliferation go to $S$ phase or differentiation David (1999) Cell cycle control system responsible genetic stability and DNA duplication and chromosome segregation Alexis et al (2017). In Eukaryote there was two control check point through the cell cycle during gap (1) and gap (2)/Mitosis .David $\boldsymbol{e t}$ al (1999) said that cell cycle activity depends on cycline dependent kinase and cycline complex (CDK-cycline) they activation and deactivation regulated by phosphorylation inhibitor or activator and they added there was 4 group from cycline (A\&B) for S,G2. and early M and (B) for G2\&M, (D\&E) for G1 to S phase, the role of a of cyclin-dependent kinases (CDKs) proteins group that act to stimulate a cell to progress through the cell cycle in response to transient p53 pulses, cells continue to cycle Alexis et al (2017).

Also there is an increase between untreated and treated cells having tetraploidy 4c DNA content, which increase about $2 \%$ to $3 \%$ than the control.This results indicated that nitrobien accelerate cell preparation in the previous stage G1 to genetic material duplication at 4D faster than control. Some researcher supported the results Ehsan (2000) and Shehab et al (2000).

At the $3 \mathrm{c}$ cell cycle the genetic material transformed from $2 \mathrm{n}$ to $4 \mathrm{n}$ DNA content where the gradually increase by a duplication process were occurred and the percentage of cells interred this phases was observed between untreated and treated cells. The previous result cleared that the variation of cells through the cell cycle phases indicated that an accumulation in cells with $3 \mathrm{c}$ and $4 \mathrm{c}$ while the percentage of cells in 2c DNA content was decrease special after 4D treated compared with control. The DNA amount is considered a good indication of where a cell stands in the cell cycle. DNA is replicated in S phase, so, cells in G2 have higher of DNA levels than cells in G1. Some researcher supported the results Ehsan (2000) and Shehab et al (2000). 4c classes contain the $4 \mathrm{n}$ amount of DNA content in G2 i.e. Tetraploidy, the cell prepare the nucleus to division, the percentage of cell in G2 increase with the doses increased with note that ,the recommended dose nearest result to control, also the fluctuated results was recorded At $5 \mathrm{c}$ classes where the percent of cells present which entering and pass to the M phase with $2 \mathrm{n}$ DNA content and prepare to enter the next division with doses increase was recorded in table (1)

Table (2) summarize the results cell cycle characteristics, where the percentage of cells through G0,G1,S,G2 phases added to percentage of Mitotic Index and Proliferation activity was considered the balance between cell loss and cell inter the division. A positive relationship between the nitrobien doses increase and percentage of cells for all parameters compared with control, except the cells in G0 and G2 phase after treated with 4D. The relation between the amount of DNA and Feulgen stain intensity appeared at plate (1), figures (1a\&b,2a\&b,3a\&b) where the nuclear chromatin Image process were recorded the nuclear size and amount of DNA in G1 compared with G2 in cells at Interphase according to staining color intensity indicated that the red color for active chromatin (Euchromatin), while the yellow color for inactive chromatin (Heterochromatin) after Vicia faba treated with biofertilizer doses compared with control.David et al (1991) found that the interrelationships between structure and function that occur in cell cycle it is essential to have information about the arrangement of chromosomes in interphase nuclei which can't be seen in the decondensed chromatin without the telomere chromosome end region, the arrangement of telomere in G1 (2n), and G2 (4n) phases cell cycle where the telomere turned to the nuclear envelope after the DNA duplication finished and DNA content was double 
with increase in nuclear size, appeared in figures (1a,2a,3a) figures $(1 \mathrm{~b}, 2 \mathrm{~b}, 3 \mathrm{~b})$ respectively, the results in agree with Mitchison (1971)

The tighter spacing of telomeric nucleosomes may reflect a higher-order chromatin structure that is conducive to telomere function Fajkus and Trifonov (2001). Linear chromosomes face two major challenges not encountered by circular chromosomes the first is to distinguish the ends from breaks in DNA strands that need repair Jonathan et al (2011)

Plate (2) followed the chromosome behavior through the mitotic division to complete the cell cycle where there are a chromosome instability at metaphase leads to telomere dysfunction phenomenon appeared as end to end fusions between non homologous chromosome or/and the sister chromatid with end joining appeared companied with satellite breakage in some treatment as an example of chromosomal aberration induced by telomere uncapping, where sister chromatid fusions (SC) and chromosome fusions that initiate breakage - fusion- bridges cycle and causes a bridge phenomenon at anaphase and telophase, also micronucleus at Interphase recorded after treated with 2D 4D Figurers $(1,2,4,5,7,8)$. This results causes aneuploidy states where some chromosome will lose with the information and the other gained. Paula et al (2009) said that end-to-end fusions result from telomere uncapping and Natarajan (2005) added that chromosomal aberrations in his 'breakage event is a chromosome break and this can remain open (break), rejoin with another break (rejoin to produce a dicentric or translocation. The mutagenic effects was as a results of chromosome aberration at metaphase stage special in telomere structure as an end-to-end fusions between sister chromosome or sister chromatid with end joining so the nondisjunction chromosome and sister chromatid failed separate them during spindle pole at anaphase, also the fusion product break at breakage-fusion-bridge cycles due to telomere behavior leads to cytokinetic failure. From this results some daughter cells will contained a dicentric chromosome while the other will lose it. Jonathan et al (2011) told that telomere was the specialized structures at the ends of chromosomes the formation of dicentric chromosomes during anaphase where the two centromeres could be pulled to opposite poles, creating an "anaphase bridge" as the two complements of chromosomes segregated as a "breakage-fusion-bridge" cycle.

Tables (3 and 4) represent a study of growth parameters where there was a significant increase in the root length with directly proportional to the increase in doses during the experiment period of 12 days where the daily increase recorded at D $(41.1 \mathrm{~cm})$. and results If return to trace the growth of the plant to the fruiting table $(\varepsilon)$ a significant increase with a direct relationship with doses compared to control were recorded, but the recommended dose was the highest value in both fresh and dry weight as well as the average number of pods / plant and the average number of seeds

The percentage of total abnormalities of Vicia faba PMCs at first and second meiotic division and percentage of different abnormalities types after treated with nitrobien biofertilizer recorded in Tables (5\&6), directly proportional with doses increase observed and the percentage of total abnormalities in the first meiotic division were less than the second division this indicates that the doses effect permanent Table (5). From the abnormal types which present with treated plant chromosome structure aberration (fragment -brake), Kinetic aberration (bridge - lagging -spindle disturbance)-Chromatin mater liquefaction (stichness) and synchronization at anaphase I \&II telophase II. 
The effect of end to end fusion as nucleate bridge causing cytokinesis at tetrads figure (7\&8b) in table (5) with a proportional with doses increase, where the bridge was considered the highest value followed by fragment and break. On the other hand, telomere uncapping or dysfunction with sister chromatid end to end fusions at diakinasis in prophase I recorded figure (1) when telomeres lose their protective telomere-binding proteins. The daughter cells end up with altered ploidies that can be severe enough to prevent cell viability. So end-to-end fusions cause problems in cells in part because fused chromosomes will likely not segregate properly during mitosis and meiosis

Plate (2) cleared that there was a chromosome instability leads to telomere dysfunction phenomenon and genomic instability appear as end to end fusions of non homologous chromosome and the same chromosome with end joining appeared in mitotic division through the Metaphase chromosome companied with satellite breakage figure (3) as an example of chromosomal aberration induced by telomere uncapping, where sister chromatid fusions (SC) and chromosome fusions that initiate cycles of breakage - fusion- bridges, ana- telophase bridge might be formed due to dicentric chromosomes, where anaphase bridge as the two complements of chromosomes segregated. The critical function of "breakage-fusion-bridge" cycle may be continued in the endosperm, but the defective chromosomes may be healed with new telomere formation Jonathan et al (2011). Also, cytokinetic failure as a polycentrosomal in Interphase cells with micronucleus appeared in figure (8a). This results lead to aneuploidy states where some chromosome or part of chromosome will lose with the information causes chromosome aberration than its normal. Lauren et al (2013) record that the aneuploidy can be described as numerical or structural, depending on whether whole chromosomes or portions of chromosomes are gained or lost. On the other hand, Vicia faba from the species that are characterized by existence satellites (subtelomeric) and it was an agronomical important satellite distribution, function, and evolution Sharma and Raina (2005)

From the mitotic and meiotic results the breakage - fusion - bridges cycle continue from the mitotic division as a result for this phenomenon daughter cells has a micronucleus at interphase figure (8b) plate (2) and figure (8a) plate(3). The results is an agreement with Paula and Maria (2011) .So the recommended dose was considered a safety dose, and advise by using the dose without over-repetition with follow-up and evaluation of its genetic effects . 
Table (1 ) Integrated optical density (I.O.D.) in Arbitrary Unit (A.U.) is expressed amount of DNA /Pico gram and DNA classes of Vicia faba after treatment with nitrobein biofertilizer compared with control

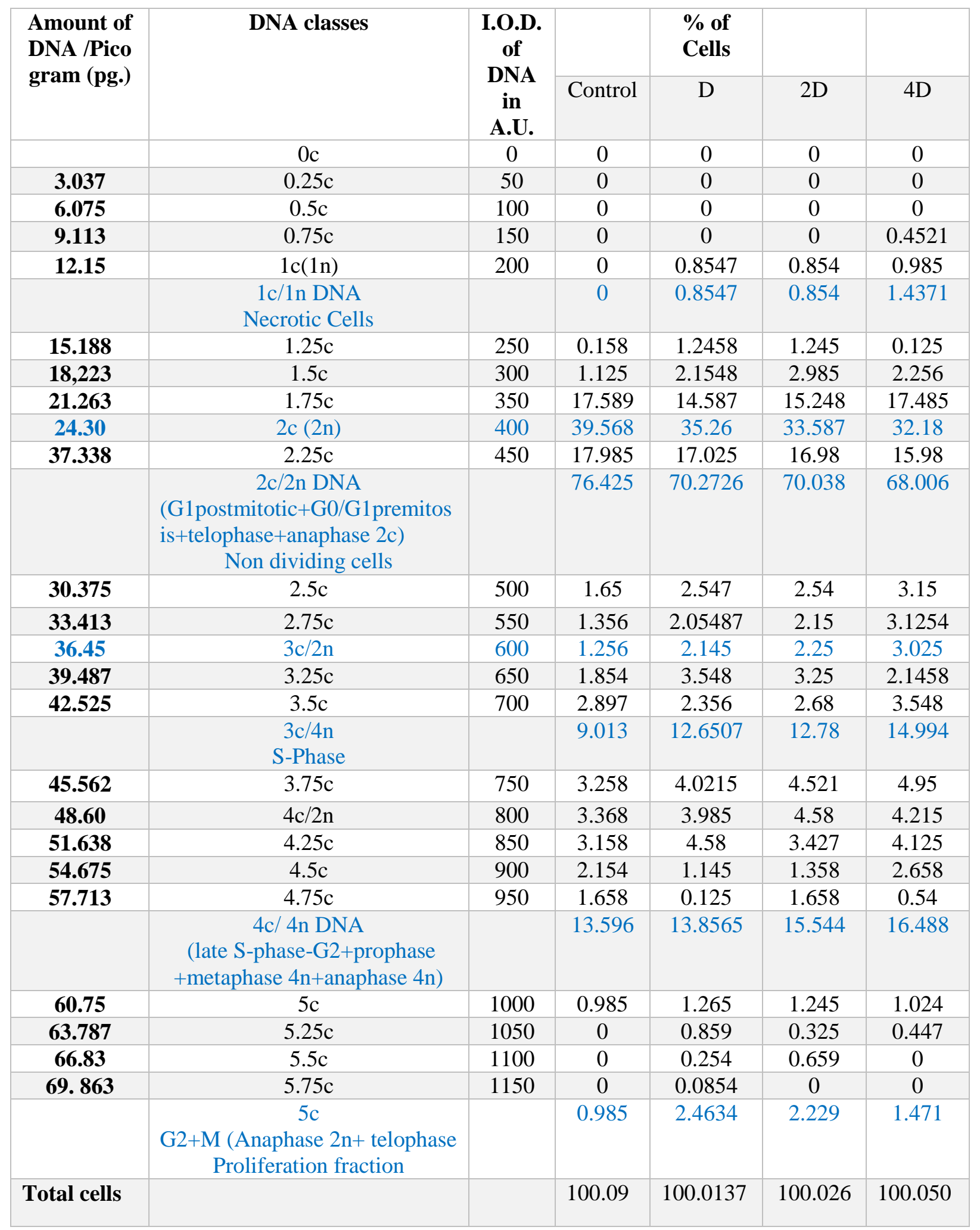


Table (2 ) DNA distribution as a \% of cells at cell cycle characteristic and mitotic phases of Vicia faba after treatment with nitrobein compared with control

\begin{tabular}{|c|c|c|c|c|}
\hline \multirow[t]{2}{*}{ Cell Cycle characteristics } & \multicolumn{4}{|c|}{$\%$ of cells } \\
\hline & Control & $\begin{array}{c}\mathrm{D} \\
\text { (recommended } \\
\text { dose) }\end{array}$ & $2 \mathrm{D}$ & $4 \mathrm{D}$ \\
\hline (Necrotic cells ) & 0 & 0.8547 & 0.854 & 1.4371 \\
\hline ( Non dividing cells) & 76.425 & 71.658 & 70.038 & 68.006 \\
\hline G0-phase & 49.658 & 46.258 & 45.128 & 40.548 \\
\hline G1-phase & 25.968 & 26.125 & 26.584 & 27.458 \\
\hline S-phase & 9.013 & 11.258 & 12.78 & 14.9942 \\
\hline G2-phase & 11.251 & 8.0284 & 7.732 & 6.63 \\
\hline Mitotic Index & 3.125 & 5.0125 & 6.125 & 7.458 \\
\hline Polyploidy & 0.985 & 2.4634 & 2.2289 & 1.471 \\
\hline Proliferation activity & 15.487 & 19.87 & 22.458 & 25.9847 \\
\hline Total cells & 100.019 & 100.0906 & 100.0147 & 100.0263 \\
\hline
\end{tabular}


Table (3) The average root length/cm of Vicia faba after treatment with nitrobein compared with control after 12 days

\begin{tabular}{|c|c|c|c|c|}
\hline \multirow{2}{*}{ Experiment } & \multicolumn{3}{|c|}{ Root length /cm } & \multirow{2}{*}{ Daily increase/cm } \\
\cline { 2 - 4 } & 4 days & 8 days & 12 days & \\
\hline Control & $2.5 \pm 0.5$ & $6 \pm 0.7$ & $11.4 \pm 0.9$ & $0.73 \pm 0.08$ \\
\hline $\begin{array}{c}\text { D } \\
\text { (Recommended } \\
\text { dose) }\end{array}$ & $3.5 \pm 0.2$ & $6.5 \pm 0.2$ & $13.2 \pm 0.72$ & $0.8 \pm 0.13$ \\
\hline 2D & $3.6 \pm 1.4$ & $8.5^{*} \pm 0.4$ & $16.2^{*} \pm 1.2$ & $1.05 \pm 0.05$ \\
\hline 4D & $4.2 \pm 0.25$ & $8.1^{*} \pm 0.38$ & $18^{*} \pm 1.1$ & $1.1 \pm 0.23$ \\
\hline
\end{tabular}

* Significant at 0.05 level (t-test)

Table ( 4 ) The average Shoot length after 8 weeks, dry weight \& fresh weigh/g after 70 days and no of pod /plant no of seed/ plant of Vicia faba after treatment with nitrobein compared with control

\begin{tabular}{|c|c|c|c|c|c|c|c|c|c|}
\hline \multirow{2}{*}{$\begin{array}{c}\text { Experime } \\
\text { nt }\end{array}$} & \multicolumn{5}{|c|}{ Average Shoot length } & \multirow{2}{*}{$\begin{array}{c}\text { Fresh } \\
\text { weight } \\
\text { /g } \\
\text { After } 70 \\
\text { day }\end{array}$} & \multirow{2}{*}{$\begin{array}{c}\text { Dry } \\
\text { weight } \\
\text { / g } \\
\text { After } \\
70 \text { day }\end{array}$} & \multirow{2}{*}{$\begin{array}{c}\text { average } \\
\text { no. of } \\
\text { pods } \\
\text { /plant }\end{array}$} & \multirow{2}{*}{$\begin{array}{c}\text { averag } \\
\text { e no. of } \\
\text { seeds / } \\
\text { plant }\end{array}$} \\
\hline & $\begin{array}{c}1 \\
\text { week }\end{array}$ & $\begin{array}{c}2 \\
\text { weeks }\end{array}$ & $\begin{array}{c}3 \\
\text { weeks }\end{array}$ & $\begin{array}{c}4 \\
\text { weeks }\end{array}$ & $\begin{array}{c}8 \\
\text { weeks }\end{array}$ & & & & \\
\hline Control & $\begin{array}{c}6.8 \\
\pm 0.6\end{array}$ & $\begin{array}{c}15 \\
\pm 0.2\end{array}$ & $\begin{array}{c}26 \\
\pm 1.6\end{array}$ & $\begin{array}{c}33.5 \\
\pm 0.74\end{array}$ & $\begin{array}{l}54.8 \\
\pm 0.6\end{array}$ & $\begin{array}{c}8.6 \\
\pm 0.56\end{array}$ & $\begin{array}{l}0.8^{* *} \\
\pm 0.05\end{array}$ & $\begin{array}{c}13 \\
\pm 0.82\end{array}$ & $\begin{array}{c}38 \\
\pm 0.49\end{array}$ \\
\hline $\begin{array}{c}\text { D } \\
\text { (Recomm } \\
\text { ended } \\
\text { dose ) }\end{array}$ & $\begin{array}{c}7.8 \\
\pm 0.37\end{array}$ & $\begin{array}{c}19.4^{*} \\
\pm 0.9\end{array}$ & $\begin{array}{c}23 \\
\pm 0.5\end{array}$ & $\begin{array}{c}34 \\
\pm 0.3\end{array}$ & $\begin{array}{c}59^{*} \\
\pm 0.75\end{array}$ & $\begin{array}{c}13 \\
\pm 0.92\end{array}$ & $\begin{array}{l}1.7 \text { * } \\
\pm 0.2\end{array}$ & $\begin{array}{l}18 \% \\
\pm 1.25\end{array}$ & $\begin{array}{c}44 \\
\pm 3.85\end{array}$ \\
\hline $2 \mathrm{D}$ & $\begin{array}{c}8^{*} \\
\pm 0.39\end{array}$ & $\begin{array}{l}16.2 \\
\pm 0.9\end{array}$ & $\begin{array}{c}20 * \\
\pm 1.04\end{array}$ & $\begin{array}{c}35.4 \\
\pm 0.52\end{array}$ & $\begin{array}{c}62.3^{* * *} \\
\pm 0.59\end{array}$ & $\begin{array}{c}11 \\
\pm 0.69\end{array}$ & $\begin{array}{l}0.9^{* * *} \\
\pm 0.05\end{array}$ & $\begin{array}{c}15 \\
\pm 1.25\end{array}$ & $\begin{array}{c}40 \\
\pm 0.94\end{array}$ \\
\hline 4D & $\begin{array}{c}6 \\
\pm 0.77\end{array}$ & $\begin{array}{c}14 \\
\pm 0.4\end{array}$ & $\begin{array}{l}20.2^{*} \\
\pm 1.55\end{array}$ & $\begin{array}{l}40^{* *} \\
\pm 0.75\end{array}$ & $\begin{array}{l}63 \text { ** } \\
\pm 0.45\end{array}$ & $\begin{array}{c}10.2 \\
\pm 0.81\end{array}$ & $\begin{array}{c}0.7 \\
\pm 0.01\end{array}$ & $\begin{array}{c}15 \\
\pm 0.47\end{array}$ & $\begin{array}{c}40 \\
\pm 1.8\end{array}$ \\
\hline
\end{tabular}

*Significant at 0.05 level (t-test)

*** Highly Significant at 0.01 level(t-test)

no. $=$ number 
Table (5): Percentage of total abnormalities PMCs in first and second meiotic division of Vicia faba after treated with nitrobien biofertilizer

\begin{tabular}{|c|c|c|c|c|c|c|c|c|}
\hline \multirow[t]{2}{*}{$\begin{array}{c}\text { Experim } \\
\text { ent }\end{array}$} & \multirow[t]{2}{*}{$\begin{array}{c}\% \text { of } \\
\text { abnormal } \\
\text { cells in } \\
\text { first } \\
\text { division }\end{array}$} & $\begin{array}{c}\text { Diakinasis } \\
\text { \&Metaph } \\
\text { ase I }\end{array}$ & $\begin{array}{c}\text { Ana- } \\
\text { Telopha } \\
\text { se I }\end{array}$ & \multirow{2}{*}{$\begin{array}{c}\text { \% of } \\
\text { abnorm } \\
\text { al cells } \\
\text { in } \\
\text { second } \\
\text { division }\end{array}$} & $\begin{array}{c}\text { Metaph } \\
\text { ase II }\end{array}$ & $\begin{array}{c}\text { Ana- } \\
\text { Telopha } \\
\text { se II }\end{array}$ & \multirow{2}{*}{$\begin{array}{c}\text { Average } \\
\% \text { of } \\
\text { total } \\
\text { abnorm } \\
\text { al cells } \pm \\
\text { S.E } \\
\text { from } \\
\text { five } \\
\text { buds } \\
\end{array}$} & Tetrads \\
\hline & & $\begin{array}{c}\text { \%of } \\
\text { abnormal }\end{array}$ & $\begin{array}{c}\text { \%of } \\
\text { abnormal }\end{array}$ & & $\begin{array}{c}\text { \%of } \\
\text { abnormal }\end{array}$ & $\begin{array}{c}\text { \%of } \\
\text { abnormal }\end{array}$ & & $\begin{array}{c}\text { \%of } \\
\text { cytokines }\end{array}$ \\
\hline control & $0.6 \pm 0.14$ & 0.5 & 0.7 & $\begin{array}{c}1.2 \pm \\
0.2 \\
\end{array}$ & 0.7 & 1.6 & $0.9 \pm 0.1$ & 00.00 \\
\hline $\bar{D}$ & $4.3^{* *} \pm 0.7$ & 4.4 & 4.5 & $\begin{array}{c}5.1^{* *} \pm 0 \\
.5\end{array}$ & 4.0 & 6.5 & $\begin{array}{l}4.8^{*} \\
\pm 0.6\end{array}$ & 3.80 \\
\hline $2 D$ & $4.9 * \pm 0.7$ & 4.7 & 5.10 & $\begin{array}{c}6.0^{*} \pm 0 \\
6\end{array}$ & 5.6 & 6.3 & $\begin{array}{c}5.0^{* * *} \pm \\
0.9\end{array}$ & 4.10 \\
\hline 4D & $5.8^{*} \pm 1.2$ & $\overline{5.4}$ & 6.2 & $\begin{array}{c}6.55^{* * *} \pm \\
0.5\end{array}$ & 6.0 & 7.1 & $\begin{array}{c}6.2^{*} \pm \\
0.9\end{array}$ & 4.90 \\
\hline
\end{tabular}

*Significant at 0.05 level (t-test)

** Highly Significant at 0.01 level(t-test)

Table (6): Percentage of different types of abnormalities of Vicia faba buds treated with nitrobien biofertilizer

\begin{tabular}{|c|c|c|c|c|c|c|}
\hline \multirow[t]{3}{*}{$\begin{array}{l}\text { Experimen } \\
\text { t }\end{array}$} & \multicolumn{6}{|c|}{$\begin{array}{l}\text { \% of the types of abnormal PMCs in I\&II division } \\
\text { Chromosome Structure aberration (fragment -brake ) } \\
\text { Kinetic aberration ( bridge - lagging -spindle disturbance) } \\
\text { Chromatin mater liquefaction (stichness) - and Synchronization }\end{array}$} \\
\hline & Bridge & $\begin{array}{c}\text { Fragment } \\
- \\
\text { Breakage }\end{array}$ & Lagging & $\begin{array}{c}\text { Spindle } \\
\text { disturbance }\end{array}$ & Synchronization & $\overline{\text { Stichness }}$ \\
\hline & $\begin{array}{c}\% \text { of } \\
\text { PMCs }\end{array}$ & $\begin{array}{c}\% \text { of } \\
\text { PMCs }\end{array}$ & $\begin{array}{l}\% \text { of } \\
\text { PMCs }\end{array}$ & $\begin{array}{c}\% \text { of } \\
\text { PMCs }\end{array}$ & $\begin{array}{c}\% \text { of } \\
\text { PMCs }\end{array}$ & $\begin{array}{c}\% \text { of } \\
\text { PMCs }\end{array}$ \\
\hline Control & 00.00 & 00.00 & 00.00 & 60.00 & 00.00 & 40.00 \\
\hline $\mathbf{D}$ & 30.8 & 21.9 & 17.1 & 19.8 & 3.40 & 7.80 \\
\hline $2 \mathrm{D}$ & 33.7 & 22.3 & 16.9 & 18.3 & 3.80 & 5.00 \\
\hline 4D & 33.7 & 22.2 & 16.8 & 16.6 & 4.50 & 6.20 \\
\hline
\end{tabular}




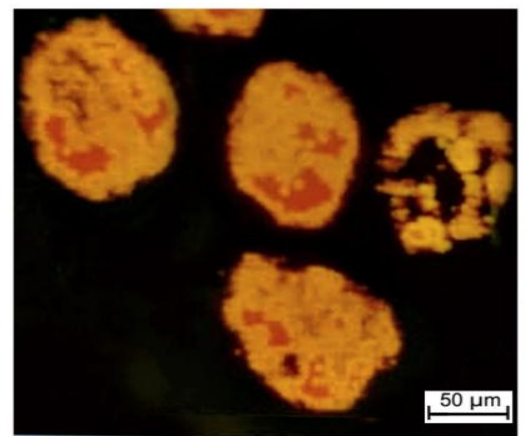

Fig.(1a)

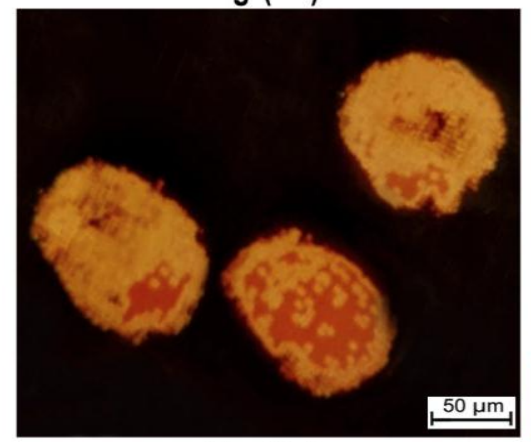

Fig.(2a)

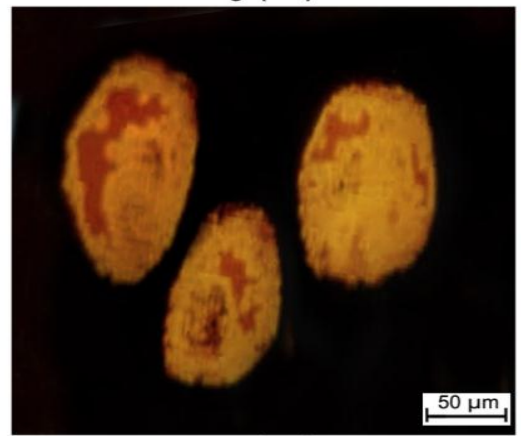

Fig.(3a)

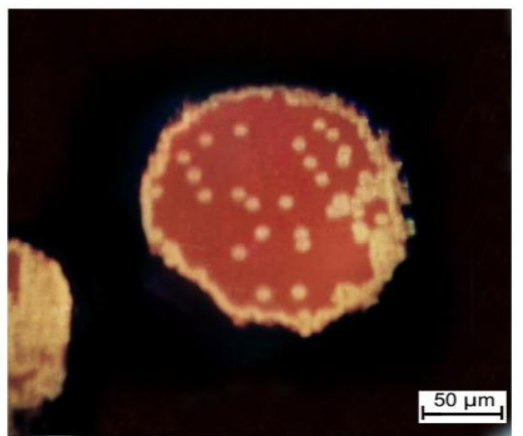

Fig.(1b)

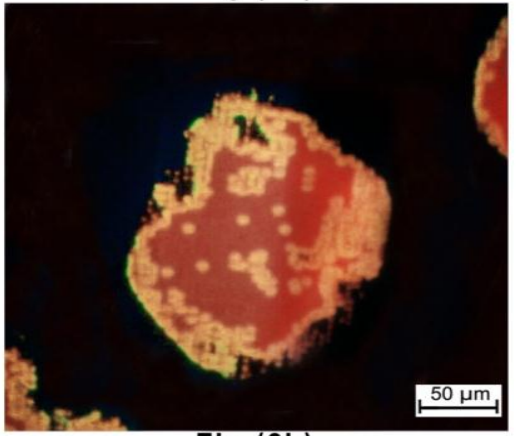

Fig.(2b)

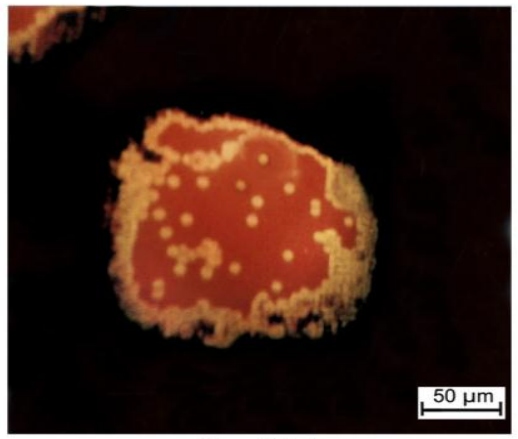

Fig.(3b)

\section{Plate (1): Nuclear Image Analysis Monitor Picture Photograph 10x10x45}

Vicia faba cells at Interphase the nuclear chromatin Image process were recorded the nuclear size and relation between amount of DNA and staining color intensity in G1 compared with G2, where the red color indicated active chromatin (Euchromatin), while the yellow color indicated inactive chromatin (Heterochromatin) after treatment with D,2D,4D doses of nitrobien biofertilizer, and the telomere turned to the envelope after the DNA duplication finished, where DNA content was doubles with nuclear size increases during the cell cycle.

Figures (1a,2a,3a) the nuclei in G1 phase with 2n DNA after treated with D,2D ,4D

Figures $(1 b, 2 b, 3 b)$ the nuclei in G2 phase with 4n DNA with D, 2D and 4D doses 


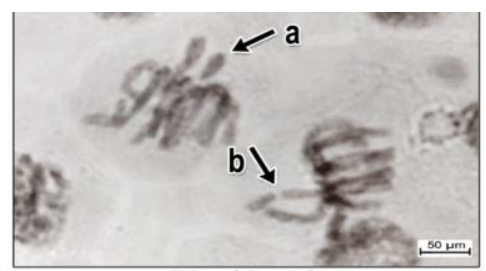

Fig.(1a,b)
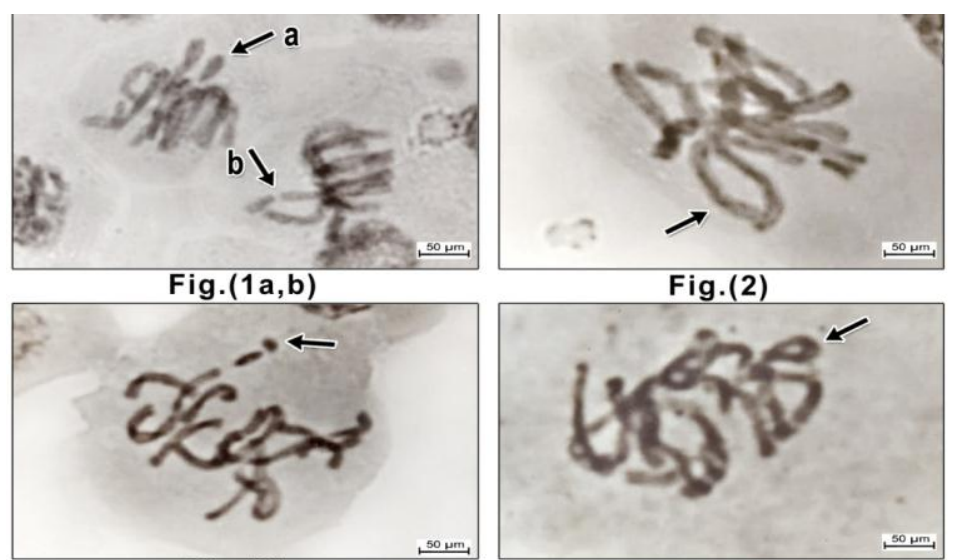

Fig.(3)

Fig.(4)

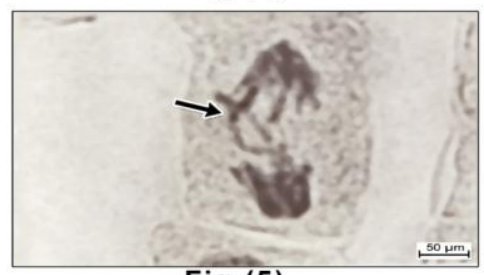

Fig.(5)

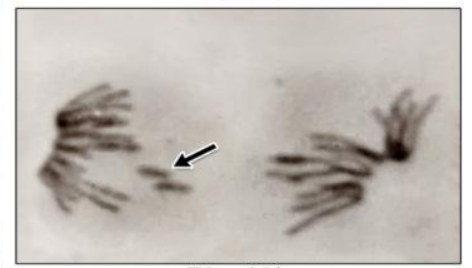

Fig.(6)

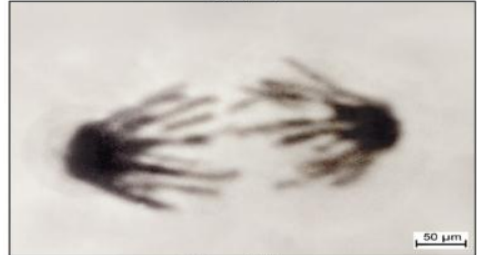

Fig.(7)

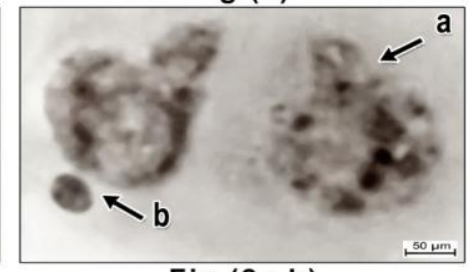

Fig.(8a,b)

Plate (2): Types of abnormalities in somatic cells at metaphase Figures (1-4) after treated with $2 D$ and $4 D$ and at anaphase Figures (5-7) after with D, 2D and 4D doses

Figures: (1a\&b2): chromosomes with end joining in Metaphase, where sister chromatid and sister chromosome fusions (SC) respectively to form end-to-end fusion resulted two chromosome ends fused together.

Figure (3): Telomere uncapping as a result of satellite fraction in subtelomeric part from chromosome after treated with 4D

Figure (4): Sister chromatid end to end fusion in same chromosome initiate cycles of breakage fusion- bridges due to telomere defects after treated with $\mathrm{D}$

Figure: (5):Sister chromosome fusions attached with one anaphase pole after treated with 2D.

Figure (6): Chromatids brake at anaphase after treated with 2D dose

Figure (7): Bridge with chromatid fragment at anaphase as a result of breakage -fusion- bridgecycle after treated with 4D dose 
Figure ( 8 a \& b): Daughter cells have Cytokinetic failure and micronucleus at interphase after treated after treated with $4 \mathrm{D}$

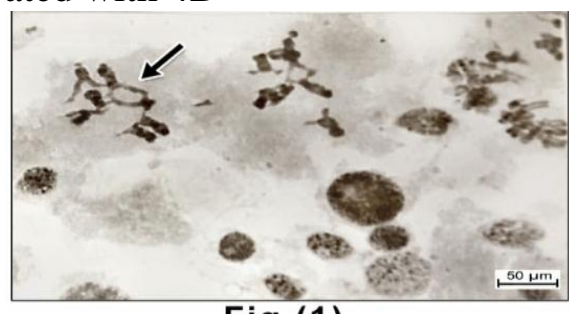

Fig.(1)

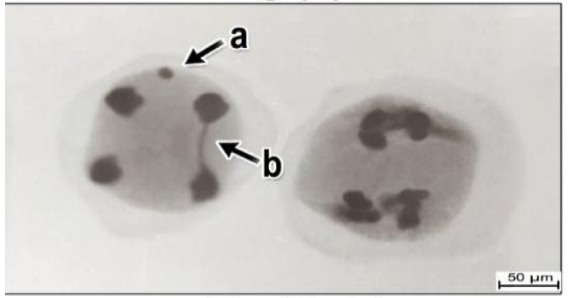

Fig.(3a,b)

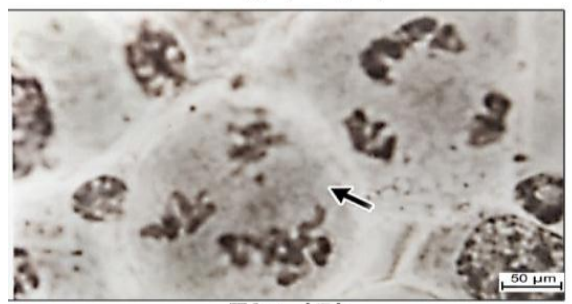

Fig.(5)

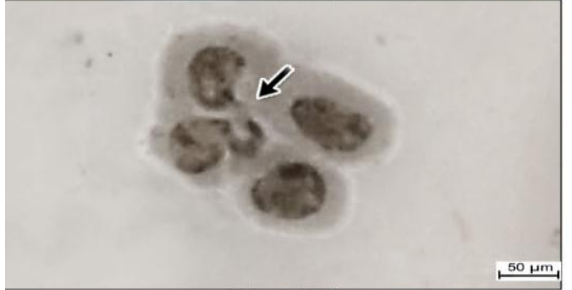

Fig.(7)

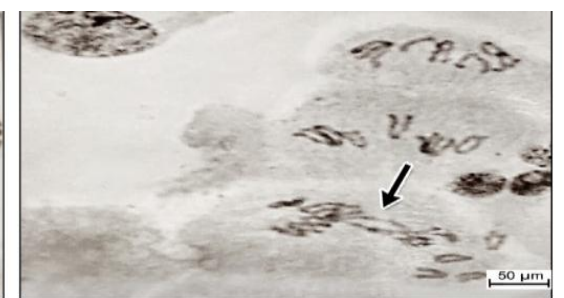

Fig.(2)

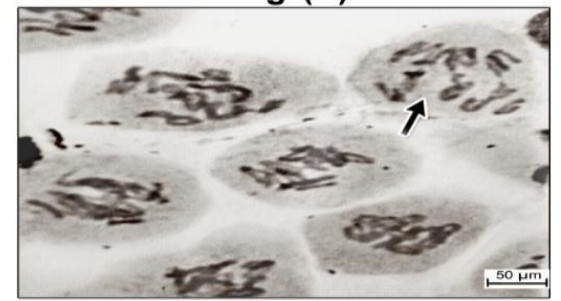

Fig.(4)

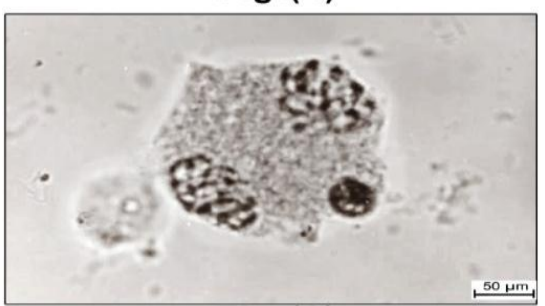

Fig.(6)

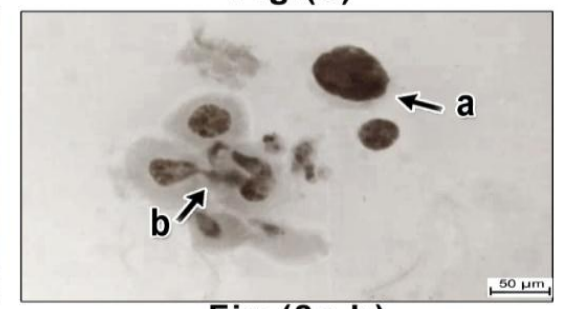

Fig.(8a,b)

Plate (3): Plate (3): Types of abnormalities in gametic cells after treatments with $D, 2 D$ and 4D doses

Figures (1-8) indicate different types of aberration in pollen mother cells at first and second meiotic division

Figures $(1 \& 2)$ : End to end fusions of chromosomal aberration induced by telomere uncapping or dysfunction was observed, with univalent chromosome fusions (SC) that initiate breakage fusion - bridges cycle at Diakinasis in Prophase I and Anaphase I respectively after 2D dose

Figures (3a\&b): Sticky telophase II with bridge and fragment after treated with D dose

Figure (4): Spindle Disturbance anaphase II after 2D dose

Figures: (5\&6): Synchronization in Anaphase II , Prophase II after 4D dose 
Figures (7\&8a): Cytokinesis as a result for progressive telomere dysfunction with bridge at tetrads $4 \mathrm{D}$ dose

Figure (8 b): micronucleus at Interphase in daughter cell after 2D dose

\section{References :}

Abdel-Hamid R.S., (2007) :The mutagenic effect of some fertilizers on some higher plants . M.Sc. Thesis, Department of Botany, Faculty of Science Zagazig University.

Alexis R. B., Cooper S., Frank S. H., Francesca B., Henriette S., Jörg M., Béla N. and Chris B. (2017) :DNA damage during $S$-phase mediates the proliferation-quiescence decision in the subsequent G1 via p21 expression Nature Communications volume 8, Article number: 14728 https://www.nature.com/articles/ncomms14728

Brugal G. (1984): Image analysis of microscope preparation. In Jasmin G. and Proschek L.(eds.) Methods and Achievements in Experimental Pathology Basel Kager (11) pp1-33.

Cooper G.M. (2000): The cell A Molecular Approach. $2^{\text {nd }}$ edition Sunderland (MA) Sinauer Associates; 2000 https://www.ncbi.nlm.nih.gov/books/NBK9876

Darlington, C.D. and La-cour, L.F. (1976): The handling of chromosomes. Sixth Ed., George Allen and University, LTD London

David J. R., Martin I. H., and Peter J. S. (1991): Localization of telomeres in plant interphase nuclei by in situ hybridization and 3 D confocal microscopy. Chromosoma $100: 424$ 431

Dean P.N. (1980): A simplified method of DNA distribution analysis. Cell Tissue Kinet.13:299308.

Ehsan N.O. (2000): Studied the Mutational and Cytogenetic effects of some Biofertilizers. PH.D. Thesis Botany Department, Faculty of Women For Arts, Science and Education, Ain Shams University, Cairo, Egypt.

Elliot G., Richard M. D. and Yoo K. (1988): Applications of Computerized Microscopic Image Analysis in Infectious Diseases. Journal of Infectious Diseases 10(1):92-102.

El-Shazly H.H. and El-Sheik I.A. (2000): Arrest of mitotic cycle and induction of chromosomal aberrations by aflatoxin B2 in root cells of Vicia faba. Cytologia 65:112-113

Fajkus J., Trifonov E.N. (2001) Columnar packing of telomeric nucleosomes. Biochem Biophys. Res. Commun. 280:961-963 PubMed Google Scholar

Garbay C. Brugal G. and Chaquet C. (1981): Application of colored Image analysis to Bone marrow cell recognition. Anal Quant, Cytologia. (3): 272-280 
Glab N., Labidi B., Bergounioux C. and Meijer L. (1994): Olomoucine, an inhibitor of the cdc2/cdkc2 kinases activity, blocks plant cells at the $\mathrm{G} 1$ to $\mathrm{S}$ and $\mathrm{G} 2$ to $\mathrm{M}$ cell transitions F.E.B.S let. 353:207.

Hammat N.M., Blackhall N. w., and Davey M.R. (1991): Variation in the DNA content of Glycine species. J. Exp. Bot. 42: 659-665.

Hande M. P., Samper E., Peter L., Maria A. B. (1999): Telomere Length Dynamics and Chromosomal Instability in Cells Derived from Telomerase Null Mice journal of cell biology.144(.4).589 DOI: 10.1083

Hans N., Jörg R., and Do H. M. (1997) :Heterogeneity of DNA distribution pattern in renal tumors Analytical Cellular Pathology 14 9-17 9

\section{http://jcb.rupress.org/content/9/2/445.abstract}

J.Van'T Hof (1974): The duration of chromosome DNA synthesis. Hand Book of Genetics. Vol. 11, R.C. King (Ed.) Plenum, New York Vol. 10, No. (1) pp. 92-102 .https://www.jstor.org/stable/445427

Jean C. D. , Millot-B. Z., Oum'Hamid F., Liautaud R. (1995): Nuclear DNA and chromatin texture in multidrug-resistant human leukemic cell lines International Journal of Cancer 60(1):10814 .

Jean D., Marie-F. P. B. and Sonia Y. (2000): Nuclear DNA content and chromatin pattern of rat rhabdomyosarcoma cell sublines with different metastatic potentials. Analytical cellular pathology: the journal of the European Society for Analytical Cellular Pathology 20(1):41-8

Jnawali A. D., Ojha R. B., Marahatta S., ( 2015) : Role of Azotobacter in soil fertility and sustainability-a review. Adv. Plants Agric. Res.; 2 (6):1-4

John W., Ellen R., Hewson S. (1961): Nucleic Acid and Protein Metabolism During the Mitotic . Cycle in Vicia faba 9 (2): 445

Jonathan C. L., Eugene V. S., and Dorothy E. S. ( 2011) : Plant Telomeres Part of the Plant Genetics and Genomics: Crops and Models book series (PGG, volume 4) https://link.springer.com/chapter/10.1007/978-0-387-70869-0_7

Kyi M. , Aung Z. H. , Seinn M., Khin M. S. (2019) : Effects of Biofertilizer Produced from Bradyrhizobium and Streptomyces griseoflavus on Plant Growth, Nodulation, Nitrogen Fixation, Nutrient Uptake, and Seed Yield of Mung Bean, Cowpea, and Soybean Agronomy 2019, 9, 77; www.mdpi.com/journal/agronomy

Laura Á. R. ,Andrea K. , Petr N. , and Katharina B. ( 2018) : Satellite DNA in Vicia faba is characterized by remarkable diversity in its sequence composition, association with centromeres, and replication timing Scientific Reports 8(1):5838 DOI: 10.1038/s41598-018-24196- 
Lauren M. Z. , Eric M.C.B., and Beth A. W. (2013): 2n or not 2n Aneuploidy, polyploidy and chromosomal instability in primary and tumor cells. Semin Cell Dev. Biol. 24(4): 370-379

Lucie N. and Jiri S. (2012): NBS1 plays a synergistic role with telomerase in the maintenance of telomeres in Arabidopsis thaliana. BMC Plant Biology12:167

Martin P. (1971): The Biology of the Cell Cycle. By J. M. Mitchison. Cambridge University Press, Volume57Pp. 313. https://doi.org/10.1113/expphysiol.1972.sp002169

Michaël T., Victoria V. H., Yéhia M., Marie P. M. and Jean D. M. (1991) : Effects of Gossypol on the Cell Cycle in T-47D human Breast Cancer Cells . Anticancer research 11: 14691476

Moustafa Y., Desheash, M. and Sherby, S. (1988): Effect of gossypol on the mammalian mitotic cell cycle and DNA synthesis. Bull. High Inst. Public Health, Vol., XVII (4): 787-798

Natarajan A. T. (2005): Chromosome aberrations Plants to human and Feulgen to FISH. Current Science, VOL. 89, NO. 2 335-340

Paula M. and Maria A. B. (2011): Telomeric and extra-telomeric roles for telomerase and the telomere-binding proteins. Natural Reviews CANCER 11, 161-176

Paula M., Maria T., Purificación M., Chunyan L., Agueda T., Carolyn M., Juana M. F., Oscar F.C., Madalena T., and Maria A. B. (2009): Increased telomere fragility and fusions resulting from $T R F 1$ deficiency lead to degenerative pathologies and increased cancer in mice Genes \& Development 1; 23(17): 2060-2075.

Sharma S. and Raina S.N. (2005): Organization and evolution of highly repeated satellite DNA sequences in plant chromosomes. Cytogenetic Genome Research 109:15-26

Thoria, R. M., Amal, S.S., and Nahla O.E. (2003): Effect of Two Biofertilizers Rhizobactererien and Phosphoren on Morphological and Meiotic Division in Vicia faba. Bull. Fac. Sci., Assiut university. 32 (1-D), 1-15

Yaso, I.A., Abdel-Razzak H.S. and Wahab A. M.A. (2007): Influence of Biofertilizer and Mineral Nitrogen on Growth, Yield and Quality Under Calcareous Soil Conditions. Journal of Agriculture \& Environmental Science Alexandria University, Egypt Vol.6 (1) 542 


\section{الملخص باللغة العربية}

تأثير المخصب الحيوى النيتروبين على التغيرات الوراثية الخلوية ومعايير النمو لتبات الفول نهلة عثمان محمد احسان

\section{قسم النبات ـ كلية البنات للآداب والعلوم والتربية ـ جامعة عين شمس

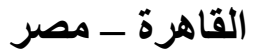

يكهف البحث دراسة تأثير معاملة نبات الفول البلدى بالمخصب الحيوية النيتروبين بجر عات تبدأ من الجرعة الموصى بها والضعف الضعفين مقارنة بالغير معاملة لتتبع التغيرات المورفولوجية وقياس النمو بدأ من البادرة للنبات الكامل واستخدامت الدراسة الميكروسكوبية لدر اسة التخيرات الوراثة الخلوية عبر الانقسام الميتوزى من خلال تحليل صورة النواة وتقدير التباين في محتوى المادة الوراثية فى الطور البينى على أساس العلاقة بين الحمض النووي وصبغة Feulgen بفحص Eeuchromatin و Heterochromatin وكذلك تقدير نسبة الخلايا التي تدخل دورة الخلية ، كمؤشر على حيوية الخلية والنسبة المئوية لمعدل الانقسام محتوى الحمض النووي خلال G1 G ، G2 ودرجة نشاط الخلايا من دورة الخلية ، إضافة إلى تتبع سلوك الصبغيات فى الانقسامين الميتوزى والميوزى .حيث سجلت النتائج وجود أنواع من الشذوذ الكروموسومى فى النباتات المعاملة فى علاقة طردية مع الزيادة فى الجرعات المستخدمة ( D، I و D و مقارنة بالنباتات الغير معاملة مصحوبًا بتأثيرات مطفرة في مرحلة الطور الاستوائى والانفصالى من الانقسام الميتوزى و الميوزى متمثلة فى الجسور والكسور الكروموسومية اضافة إلى الكروموسوم ذو النهاية الملتصقة على مستوى الكروموسومات المتجاورة أو الكروسوم ملتصق مع نفسه نتيجة لخلل في شكل وحيوية التيلومير وهو جزء هام فى نهاية الكروموسومات للحفاظ عليه بسبب المعاملات المستخدمة بذلك استمرت أنواع الثذوذ فى الظهور من الخلايا الجسدية إلى الخلايا المشيجية في الانقسام الميوزى اضافة إلى وجود خلل فى مرحلة الرباعيات حيث استمر اتصال النويات عن طريق القناطر المتكونة سابقا رغم تكون الغثاء النووى خصوصا فى النباتات المعاملة بجرعة 4D ـ وفي در اسة معايير النمو للنباتات المعاملة بجرعات النيتروبين كان هنالك زيادة معنوية تنتاسب طرديا مع المعاملات المستخدمة فى كل من طول الجزر والساق وكانت أفضل النتائج المسجلة لمتوسط عدد القرون وعدد البذور /للنبات النباتات المعاملة بالجرعة الموصى بها مقارنة بالنباتات الغير معاملة. لذلك اعتبرت الجرعة الموصى بها جر عة آمنة دون التكرار الز ائد مع ، و عند استخدام الجر عة بالطريقة الموصى بها بوصى البحث بمتابعة وتقييم الآثار الناتجة ور اثيا . 